\title{
Capital Gains Taxation and the Cost of Capital: Evidence from Unanticipated Cross-Border Transfers of Tax Bases
}

\author{
Harry Huizinga \\ (Tilburg University and CEPR) \\ Johannes Voget \\ (University of Mannheim, Oxford University Centre for Business Taxation, \\ Tilburg University CentER) \\ and \\ Wolf Wagner \\ (Tilburg University)
}

June 2011

\begin{abstract}
In a cross-border takeover, the tax base associated with future capital gains is transferred from target shareholders to acquirer shareholders. Cross-country differences in capital gains tax rates enable us to estimate the discount in the takeover price on account of future capital gains. The estimation suggests that a one percentage point increase in the capital gains tax rate reduces the valuation of new equity by $0.136 \%$. The implied average effective tax rate on capital gains is $4.57 \%$, indicating that capital gains taxation is a significant cost to firms when raising new equity capital. Apart from the taxation of future capital gains, we also find that takeover prices are affected by capital gains taxation resulting from the accelerated realization of past capital gains by target shareholders.
\end{abstract}

Key words: Capital gains taxation, Cost of capital, International takeovers, Takeover premium JEL classification: G32, G34, H25 


\section{Introduction}

Shareholder-level capital gains taxation reduces the attractiveness of assets such as shares for which a large part of total investor returns comes in the form of capital gains. Thus, capital gains taxation potentially depresses share prices, and raises the cost of equity finance to firms. The measurement of the impact of capital gains taxation on the cost of capital, however, has proven difficult. This reflects that the capital gains tax is a rather complex tax. Capital gains taxes are only assessed on realized gains, and even then the capital gains tax base can be reduced by taking exemptions and deductions for realized losses. Individuals thus can reduce their capital gains tax liability by holding on to their appreciated assets, or by realizing gains that are wholly or in part offset by losses, reducing the effect of capital gains taxation on the cost of capital. Ivković, Poterba, and Weisbenner (2005) provide evidence of trading by individual investors aiming to reduce the effective capital gains tax burden.

In this paper, we exploit cross-border M\&A data to estimate the impact of capital gains taxation on asset pricing and the cost of capital. In a cash-financed cross-border takeover, the tax base associated with future capital gains is transferred from target shareholders to acquirer shareholders. These two groups of shareholders generally are subject to different capital gains tax regimes. This enables us to estimate the impact of a change in the capital gains tax rate, triggered by the change in international ownership, on asset valuation. More specifically, the takeover price should reflect the capital gains tax burden to acquiring shareholders associated with expected capital gains subsequent to the takeover. The prices of new shares issued for the purpose of financing real investment should similarly reflect the future capital gains tax burden associated with these shares. Thus, our estimated discount of capital gains taxes in takeover prices informs about the pricing of new shares generally, and thus about the cost of equity capital.

The use of international M\&A data to estimate the impact of newly applicable capital gains taxation on the prices of equity has five distinct advantages. First, our sample of international M\&As allows for significant variation in capital gains tax rates across countries and over time. Second, the change in applicable capital gains taxation triggered by an international takeover is generally unexpected, unlike capital gains tax introductions or changes at the national level. Third, as an M\&A only affects a single takeover target, we can take the acquiring-country capital gains tax regime to be exogenous. Fourth, our estimated effect of a newly applicable 
capital gains tax on the takeover target does not reflect any general equilibrium effects on the return on savings or wages that potentially accompany a change of the capital gains tax rate at the national level. Finally, our estimation of the impact of acquiring-country capital gains taxes on takeover prices cannot be confounded by any valuation effect of the deferred taxation of past capital gains by this country. Our international M\&A data, in particular, enable us to estimate an unambiguous 'capitalization effect' of acquiring-country capital gains taxation on takeover prices, while controlling for a possible 'lock-in' effect on the takeover price as determined by the target-country's capital gains tax regime.

For this project, we have constructed a unique data set on the capital gains regimes of 33 countries, including European countries, Japan and the United States, for the years 1985-2007. Capital gains tax rates are found to vary widely across holding periods, countries, and time. In 2007, the average short-term and long-term capital gains tax rates were $18.8 \%$ and $11.4 \%$ for the countries in our study. Our M\&As sample covers 9340 deals. The average long-term capital gains tax change induced by a cross-border merger is $13.6 \%$ points. We estimate that a one percentage point increase in the acquirer country capital gains tax reduces the takeover price by $0.136 \%$. Firms that issue new equity in the capital market to finance real investment can expect a comparable discounting of future shareholder capital gains taxation. Our discount estimate implies that the effective capital gains tax, after taking account of deductions, exemptions, and deferral options, is about 19 percent of the statutory capital gains tax. Given that the average statutory tax rate is 24.2 percent in our sample, this implies an average effective capital gains tax rate of 4.57 percent. Taking into account historical dividend yields and capital gain yields for the MSCI World Index, this is equivalent to 3.4 percent of the pre-tax total shareholder return. The implied effect of capital gains taxation on the cost of equity capital is substantial.

We further find evidence that a short-term capital gains rate that exceeds the long-term rate creates a tax barrier to takeovers, as it leads target-firm shareholders to require a higher takeover premium as a compensation for the realization of capital gains at the higher short-term rate. The higher takeover price is evidence of a lock-in effect of capital gains taxation on takeover prices.

Equity-financed cross-border takeovers, unlike cash deals, have no immediate capital gains consequences. Thus, an acquiring firm has an incentive to offer equity in exchange for target-firm shares, if a cash offer has large negative capital gains implications. In line with this, 
we find evidence that the likelihood of a cash offer declines with the difference between the acquirer and the target long-term capital gains rate (as a proxy for the increase in the future capital gains taxation induced by the merger), and also with the target-country short-term capital gains tax rate relative to the target's long rate (as a proxy for the cost of realizing capital gains at the higher short-term rate).

Several papers have previously investigated the implications of capital gain taxation and capital income taxation more generally for asset values. Sialm (2009) finds an economically significant capitalization of the joint dividend and capital gains tax liability into a lower Tobin's $\mathrm{q}$ and price-earnings ratio for US data over the 1913-2006 period, relying on over-time variation in tax rates for identification. McGrattan and Prescott (2005) study the impact of corporate income taxation and shareholder taxation of dividends and capital gains on stock market valuations in the US and the UK over the 1960-2001 period. Using a calibrated growth model, they find that changes in tax policies can well explain secular changes in the valuation of corporate equity for these two countries.

Aiming to identify a capitalization effect of capital gains taxation on equity prices, Guenter and Willenborg (1999) examine the pricing behavior of new equities of small businesses that are subject to favorable capital gains taxation after a 1993 tax law change. ${ }^{1}$ The authors find that firms that benefited from reduced capital gains taxation experienced a lower one-day return following their IPO. This is taken as evidence of higher equity prices for firms that are subject to lower capital gains taxation. Dai, Maydew, Shackelford and Zhang (2008) find evidence of both capitalization and lock-in effects in share prices in the secondary market by considering equity pricing before and after the 1997 US capital gains tax rate cut. A capitalization effect is identified by showing that nondividend-paying stocks did relatively well before the implementation of the tax cut, while a lock-in effect is identified by showing that stocks with large past appreciation did relatively badly after the implementation. ${ }^{2}$ Using a sample of IPOs, Reese (1998) similarly finds that stocks that appreciated prior to long-term qualification exhibit decreased returns after their qualification date consistent with a lock-in effect, while stocks that

\footnotetext{
${ }^{1}$ Auerbach and Hassett (2006) study the capitalization effects of cut of the US dividend tax from 35 percent to 15 percent following the Jobs and Growth Relief Act of 2003. We do not examine dividend taxation in this paper. ${ }^{2}$ Lang and Shackelford (2000) similarly find that stocks with high dividend yields did relatively badly in the week when Congress agreed the 1997 capital gains tax cut as evidence of a capitalization effect.
} 
depreciated prior to long-term qualification exhibit lower returns just prior to their qualification date consistent with a capitalization effect.

Several papers mainly are concerned with identifying a lock-in effect on stock price behavior. Among these, Jin (2006) shows that institutions serving tax-sensitive clients tend to undersell stocks with high accumulated capital gains, with measurable implications for stock price responses to large earnings surprises. Klein $(1999,2000,2001)$ shows that the tendency of tax-sensitive investors to hold on to appreciated stocks can explain long-run stock return reversal. Ayers, Lefanovitz and Robinson (2003) study the takeover premiums of (domestic) mergers in the U.S. and find that they reflect tax burdens on prior stock appreciation. They also show that the relationship between takeover premiums and capital gains tax rates is weaker for stocks that are more heavily owned by exempt institutions. By examining an international sample of M\&A that includes cross-border mergers, we can identify separate lock-in and capitalization effects of capital gains taxation on takeover premiums as the lock-in effect arises exclusively due to taxation in the target country while the capitalization effect induced by the merger is driven by tax differences between the acquirer and the target country.

Several papers have previously informed about effective levels of capital gains taxation, as opposed to statutory levels of taxation. Chay, Choi and Pontiff (2006) find that stock prices decline by less than the amount of capital gains distributions as evidence that distributed capital gains are worth less than undistributed capital gains, given that distributed capital gains are subject to immediate taxation. In effect, the relative pricing of distributed and undistributed capital gains implicitly provides a relationship between the effective capital gains tax rate and an assumed immediate rate of taxation of realized gains for the marginal investor. Protopapadakis (1983) provides additional evidence on effective capital gains taxes for US investors over the 1960-1978 period by looking at actual portfolio appreciations and capital gains tax liabilities, yielding that effective capital gains tax rates are only a fraction of statutory capital gains tax rates.

The remainder of this paper is organized as follows. Section 2 describes the capital gains taxation regimes of the various countries in our sample. Section 3 discusses the capital gains consequences of cross-border takeovers, and develops testable hypotheses of the impact of capital gains taxation on the takeover premium and the choice between cash and equity finance of a cross-border takeover. Section 4 discusses the deal data. Section 5 presents the empirical 
results. Section 6 evaluates the implications of our results for the impact of capital gains taxation on asset prices and the cost of capital, and it discusses the international repercussions of national capital gains taxes. Section 7 concludes.

\section{Systems of capital gains taxation across countries}

In the empirical work, we consider how capital gains taxation on target and acquirer shareholders affects the pricing of international takeovers. Target shareholders potentially pay capital gains taxes on their realized gains at the time of the deal, while acquirer shareholders are primarily concerned about the taxation of future capital gains. Capital gains tax rate changes are frequently announced well in advance, which implies that current and prospective tax rates may differ. In the case of the US, for instance, the current long-term capital gains tax rate of 15 percent is scheduled to increase to 20 percent after 2012. In this study, we distinguish between current and prospective capital gains taxes, keeping track of announcements of future tax rate changes.

Our study includes 33 countries consisting of a set of European countries, Japan and the United States, and it covers the period 1985-2007. For each country and each year, we have collected information on current and prospective capital gains tax rates. The main data source is the European Tax Handbook of the International Bureau of Fiscal Documentation. The tax rates apply to individuals and to cash transactions. Capital gains taxation is deferred in all countries of our sample, if target shareholders receive equity instead of cash in exchange for their shares. ${ }^{3}$

In some countries, capital gains tax rates depend on the size of the shareholding that is being sold, with substantial holdings generally taxed at a relatively high rate. ${ }^{4}$ In our study we consider exchange-listed firms, for which individual shareholdings tend to be relatively small. ${ }^{5}$ Therefore, we focus on the capital gains tax rates that apply to non-substantial holdings.

Table 1 provides information on prospective capital gains tax rates for the 33 countries in our sample as of 2007. Columns 1 and 2 provide the tax rates that apply to long-term and shortterm capital gains, respectively. In column 1, we see that 13 countries apply a long-term capital

\footnotetext{
${ }^{3}$ For example, the EU Mergers and Acquisitions Directive, adopted in 1990 and amended in 2005, stipulates that capital gains taxation is deferred if a takeover is financed with a cash share of 10 percent or smaller. One exception is Australia prior to 1999 where capital gains were taxed irrespective of the form of payment.

${ }^{4}$ Depending on the country, substantial ownership is defined as 1 percent or more of the outstanding shares.

${ }^{5}$ Sometimes different capital gains taxation is applied to listed and non-listed firms. In these cases we take the rate on listed firms to be the applicable one.
} 
gains tax rate of 20 percent or higher, while 17 countries exempt such capital gains. The average long-term capital gains tax rate is seen to be 11.4 percent.

Where long-term and short-term tax rates differ, the short-term rate tends to be higher. Austria, for instance, exempts long-term gains, but taxes short-term gains at the regular personal income tax rate, with a maximum rate of 50 percent. The UK and the US similarly tax long-term gains at 32 and 20 percent, respectively, while short-term gains are taxed at 40 and 35 percent.

The average short-term capital gains tax rate is seen to be 18.8 percent, considerably higher than the average long-term rate of 11.4 percent. Column 3 provides the threshold holding period for gains to qualify as long-term gains, if applicable. In most instances, this threshold is one year or less. The threshold exceeds one year in only three countries. These are Denmark with 3 years, France with 8 years, and the United Kingdom with 6 years. The average threshold to qualify for long-term capital gains status is 1.6 years.

The information in Table 1 can be used to calculate how average prospective capital gains taxes across countries depend on the holding period. Table 2 provides average capital gains tax rates for holding periods of 1 day, and each of a number of years ranging from 1 to 8 , with the latter number corresponding to the highest threshold in the sample. As seen in the table, the average capital gains tax rate declines from $18.8 \%$ percent for a holding period of 1 day, to 12.0 percent for a holding period of one year, and to 11.4 percent for a holding period of 8 years. ${ }^{6}$ This means that the drop is the average capital gains tax is rather sharp if we go from a holding period of a single day to a holding period of a year, while average capital gains tax rates decline only slightly for thresholds beyond one year. The realization of capital gains within a year, as potentially triggered by a takeover, thus tends to imply a significantly higher capital gains tax liability.

Next, Figures 1 and 2 show the development of prospective long-term and short-term capital gains taxation over the period 1985-2007, respectively. These figures provide trends of the average tax rates across countries, as well as for the UK and the US individually. ${ }^{7}$ Figure 1 shows an overall upward trend in the average long-term capital gains tax rate from 9.5 percent 1985 to 14.1 percent 2007. The UK long-term rate, consistent with this, increased from 30 to 34

\footnotetext{
${ }^{6}$ Thencrease in the average capital gains tax rate between the 1-year and 2-year holding period is due to scheduled increases in tax rates in some countries.

${ }^{7}$ The average numbers are computed only for countries for which capital gains tax information is available over the entire 1985-2007 period, which explains that the numbers differ somewhat from Tables 1 and 2.
} 
percent between 1985 and 2007. The US long-term rate instead was equal to 20 percent at either end of this period, even if it varied between 15 and 28 percent in the intervening period. Figure 2 in turn shows that the average short-term rate declined from 30.0 percent in 1985 to 22.7 percent in 1985. The US followed the trend, with a short-term rate of 50\% in 1985, and of 35 percent in 2007. The UK instead increased it short-term rate from 30 percent in 1985 to 40 percent in 2007. The two figures together show that the gap between the average long-term and short-term rates declined over the 1985-2007 period.

\section{Capital gains tax consequences of cross-border takeovers}

This section considers the capital gains implications of a takeover that transfers ownership of a target firm located in $i$ to an acquiring firm located in country $j$. Shareholders of the target and acquiring firms are assumed to be resident in countries $i$ and $j$, respectively. Both countries tax capital gains of their residents at the time of realization. We allow countries to make a distinction between long-term and short-term capital gains, in which case short-term gains generally are taxed at a higher rate. Let $t_{i}$ and $t_{j}$ be the long-term tax rates, while $s_{i}$ and $s_{j}$ are the short-term rates, with $s_{i} \geq t_{\mathrm{i}}$ and $s_{j} \geq t_{j}$.

The capital gains consequences of takeovers depend on whether target shareholders tender their shares in exchange for cash or for shares of the acquiring firm. In the latter scenario, the deal has no significant implications for the taxation of accrued or future capital gains. The taxation of gains accrued on target-firm shares, in particular, is deferred until target-firm shareholders sell the acquiring-firm shares that they obtain. At the same time, previous targetfirm and acquiring-firm shareholders co-own the acquiring firm after the deal, and they share in the combined firm's future capital gains, to be taxed upon realization by their respective countries of residence.

The capital gains implications of a cash-financed deal are very different, both with respect to accrued and future capital gains. To start with the latter, a cash deal implies that any future capital gains on the combined firm only accrue to shareholders resident in the acquiring country. Effectively, a cash-financed takeover transfers the capital gains tax base associated with future capital gains (on the previous target firm) from the target country to the acquiring country. This potentially has implications for firm valuation to the extent that capital gains taxes on future gains are capitalized in current share prices. The capitalization effect of capital gains taxes in 
share prices will be proportional to the long-term capital gains tax rate, if investors postpone the realization of capital gains until these qualify as long-term gains. We thus expect the discounting of future capital gains taxation in valuations to depend on the difference between the long-term tax of the acquirer and target countries, $t_{j}-t_{i}$. This leads to the following hypothesis:

Hypothesis 1: A higher difference between the acquirer and the target country long term rates, $t_{j}$ $-t_{i}$, leads to a lower premium in cash-financed transactions.

Next, a cash deal potentially has consequences for the taxation of accrued gains, as it triggers the realization of accrued gains on target-firm shares. There are two channels by which such a realization of capital gains can affect the takeover premium.

First, target-firm shareholders, who bought shares recently, are forced to realize short-term gains that may be taxed relatively heavily. The cost of doing so is proportional to the difference between the target country's short-term and long-term tax rates, i.e. $s_{i}-t_{\mathrm{i}}$. Target-firm shareholders are expected to demand a higher takeover premium to the extent short-term capital gains are taxed more heavily. This leads to our second hypothesis:

Hypothesis 2: A higher difference between the short and long term rate of the target country, $s_{j}-$ $t_{j}$, leads to a higher premium in cash-financed transactions.

Second, a cash deal accelerates the realization of capital gains on target-firm shares that already quality as long-term gains, thereby increasing the present value of such taxation. ${ }^{8}$ The cost of realizing long-term capital gains early can be taken to be proportional to the target country's long-term tax rate, $t_{i}$. Again, we expect target shareholders to demand a higher takeover premium in compensation, as summarized by the following hypothesis:

Hypothesis 3: An increase in the long term rate of the target country, $t_{i}$, leads to a higher premium in cash-financed transaction.

\footnotetext{
${ }^{8}$ The realization of long-term capital gains also eliminates the option of benefiting from generally lower capital gains taxation at the time of death.
} 
Evidence supporting Hypotheses 2 and 3 implies that selling investors require a higher price as compensation for the early realization of capital gains, consistent with a lock-in effect.

As indicated, equity-financed deals do not trigger the realization of capital gains, and they also do not affect the capital gains taxation of future capital gains. Therefore, we do not expect capital gains taxation to affect the takeover premium in equity-financed transactions. This leads to the following hypothesis:

Hypothesis 4: The premium in equity-financed transactions does not depend on capital gains taxation considerations.

Finally, we expect the choice between cash and equity finance of a takeover to be affected by capital gains taxation. ' Overall, a cash deal has 'forward-looking' capital gains consequences if the capital gains tax of the acquiring country differs from the capital gains tax of the target country, and it has 'backward-looking' consequences to the extent that target shareholders are forced to realize capital gains early and at the higher short-term capital gains tax. Any costs arising from these various aspects of capital gains taxation are making it more likely that the acquiring firm will offer equity rather than cash, as stated in the following hypothesis:

Hypothesis 5: The propensity to use cash financing decreases with i) the difference between the acquirer and the target country long-term rate, $t_{j}-t_{i}$, ii) the difference between the short and long term rate of the target country, $s_{i}-t_{i}$, and iii) the long term rate of the target country, $t_{i}$.

\section{The deal data}

The M\&A data are taken from the Thomson Financial SDC database. This database provides pricing information and other deal characteristics as well as some accounting information of the merging firms. Additional accounting data are obtained from Compustat North America and Compustat Global, while additional stock price data are retrieved from

\footnotetext{
9 Brown and Ryngaert (1991) offer a theoretical model of the mode of acquisition in takeovers, finding that acquirers with favorable private information about their stocks may offer cash despite the fact that cash offers trigger immediate capital gains taxation on appreciated stocks. Faccio and Masulis (2005) study M\&A payment choices for European bidders over the 1997-2000 period. In a robustness check, they include a capital gains indicator variable that flags target nations with individual and corporate capital gains taxation. This variable is unexpectedly positively related to the percent cash-financing in M\&A deals, but the relationship is statistically insignificant.
} 
Datastream. Our sample consists of 9340 mergers and acquisitions involving a set of European countries, Japan and the United States between 1985 and 2007. Of these, 2012 are international and 7328 are domestic. ${ }^{10}$

Table 3 provides summary statistics for the mergers, split by international and domestic mergers. The information for international mergers is broken down by target nation and by acquirer nation. The UK and the US are involved in many deals as either acquirer or target, but it is interesting to note that both countries more frequently harbor the target firm than the acquiring firm. France, Germany, Japan and the Netherlands are among the countries that relatively frequently harbor the acquirer.

The table also presents information on the mean (bid) premium in these transactions. The bid premium is calculated as the bid price relative to the market price of the target four weeks prior to the bid announcement, adjusted for the overall market price movement in the target country during the intervening four weeks. As in Officer (2003), we discard observations with a negative takeover premium or a premium exceeding 2 . The mean takeover premium for international transactions is $45.2 \%$. There is a tendency for countries that acquire relatively frequently to pay a higher average takeover premium than is paid on transactions where these countries are the targets. This is the case for France, Germany and Japan (but not for the Netherlands). Analogously, premiums on incoming transactions in the US and the UK are relatively high, while these countries are relatively frequently the target country. The table also reports the proportion of cash transactions which are subject to capital gains taxation. ${ }^{11}$ We can see that $84.7 \%$ of the mergers are such transactions.

Among the domestic mergers, the US and the UK are highly represented with 4,944 and 828 domestic M\&As, respectively. Australia, Canada and Japan each have between 300 and 400 domestic M\&As, while there are significantly smaller numbers of domestic M\&As for all other countries in the sample. The mean takeover premium for domestic M\&As is $41.7 \%$ (somewhat lower than for international mergers) and 54.8 percent of the M\&As are cash-transactions. Table 4 presents overall summary statistics for our final dataset, including besides premium, cash and tax information also various control variables used in our regression analysis.

\footnotetext{
${ }^{10}$ Domestic mergers do not allow us to identify a capitalization effect, but they contribute to the estimation of lockin effects.

${ }^{11}$ Cash and hybrid cash-equity transactions form a single category as the deferral of capital gains taxation is in many cases only possible if the cash share does not exceed $10 \%$.
} 


\section{Empirical results}

This section presents evidence on the impact of acquirer-country and target-country capital gains taxation on the takeover premium and on the choice of payment for takeovers.

\subsection{The takeover premium}

To test Hypotheses 1-3 of section 4, we relate the takeover premium to three capital gains tax terms: the cross-border long-term tax difference $t_{i}-t_{j}$, the difference between target-country short-term and long-term tax rates $s_{i}-t_{i}$, and the target-country long-term rate $t_{i}$. To construct these three tax variables, we take the short-term to be a single day, and the long term to be 5 years.

To start, we report the results of simple means tests where we compare the mean values of the premium for cash-financed transactions across two subsamples consisting of observations of one the three tax variables below and above its median. In column 1 of Table 5, we see that the mean value of the premium is 47.0 percent for low values of the cross-border tax difference, and 41.8 percent for high values of the cross-border tax difference. Thus, acquirers in high tax difference countries tend to pay lower premiums consistent with Hypothesis 1. The difference of the two mean values of 5.2 percent is statistically different from zero at the 1 percent level. In column 2, we see that the mean value of the premium for low values of the target short-long difference is 41.8 percent, while it is 43.3 percent for observations with high values of the target short-long difference. Targets located in countries with a relatively high short-term capital gains thus on average command a takeover premium that is $1.6 \%$ points higher in line with Hypothesis 2 , and this difference is significant at 5 percent. Similarly, in column 3 we see that targets located in countries with a relatively high long-term tax rates obtain a premium that on average is $1.7 \%$ points higher in accordance with Hypothesis 3 , and this difference is statistically significant at 5 percent.

Next, we present regressions that relate the takeover premium to several tax variables simultaneously and to a range of control variables. The regressions include target-country, acquirer-country and year fixed effects, and errors are clustered at the target country level. We first consider only cash-financed transactions to test Hypotheses 1-3, and subsequently consider only equity financed transactions to test Hypothesis 4. Regression 1 of Table 6 includes all three 
tax terms, and a set of firm level and deal level controls (see the Appendix for variable definitions and data sources). The cross-border tax difference obtains a coefficient of -0.151 that is significant at the 5 percent level. Thus, acquirers in countries with a higher capital gains tax rate tend to pay lower premiums, consistent with a capitalization effect of capital gains taxes in equity prices. The target-country short-term, long-term tax difference is estimated with a negative coefficient that is statistically insignificant. The target country long term rate in turn obtains a coefficient of -0.450 that is significant at the $5 \%$ level. This latter result is inconsistent with Hypothesis 3, as it suggests that bid premiums are lower when target shareholders face a higher cost of acceleration the realization of their long-term gains.

Among the control variables, targets with larger assets command significantly lower premiums. Target-firm leverage instead significantly increases the premium. This may reflect that firms with high leverage cannot borrow further to realize worthwhile growth opportunities, thereby justifying a higher premium. Acquirers also pay significantly more for targets with more liquid assets (as also used in Comment and Schwert (1995) and Ayers, Lefanowicz, and Robinson (2003)), perhaps because such targets are easier to value. Acquirers further offer significantly higher prices for targets with high book-to-market values, as such targets may be undervalued. The premium is negatively and significantly related to the target firm's return on equity, as firms with a high return on equity may offer few opportunities for further rationalization. Intra-industry mergers command significantly higher premiums, as they may pose fewer valuation problems and higher potential synergies gains. As expected, competed bids and hostile takeovers lead to significantly higher premiums, while bids made in the form of a tender offer also are significantly higher, in line with results in Schwert (1990). Finally, the percentage of acquirer ownership in the target prior to the acquisition, or the toehold, is significantly and negatively related to merger premiums, possibly reflecting higher bidder bargaining power.

A difficulty in identifying separate effects of the difference of the target country shortterm and long-term rates and the long-term rate itself in regression 1 is that the long-term tax rate affects both tax terms, giving rise to a negative correlation of -0.48 between the two tax terms. To alleviate this problem, we next assume that the capital gains taxation cost of accelerating long-term capital gains is not only proportional to the long-term tax rate, but also to the capital gains on the target country's stock market index over the last 5 years, calculated as the share of 
the contemporaneous index that is due to appreciation over the previous 5 years. We take this share of capital gains on the market index rather than on the individual target firm, as stock price information for target firms over such a horizon is only available for about a quarter of the target firms in our international merger sample. The appreciation of the index may be appropriate for calculating capital gains tax burdens, as this reflects the extent to which gains on appreciated stocks cannot be offset by losses on depreciated stocks.

Accordingly, regression 2 replaces the target-country long-term tax rate by the product of this tax rate and the five-year capital gains share for the index, which has a lower correlation with the short-long tax difference of -0.27 . The regression in addition includes the five-year capital gains share for the index itself. The cross-border tax difference variable obtains a coefficient of -0.135 that is significant at 5 percent, similar to regression 1 . The short-long tax difference now obtains a positive coefficient that is significant at the $5 \%$ level. The targetcountry long-term tax burden variable is estimated with a positive coefficient of 0.253 that is insignificant, while the capital gains share for the index is estimated with a positive coefficient that is significant at 10 percent. The insignificance of the long-term tax burden may reflect that the marginal target shareholder in M\&As is a shareholder for whom the higher short-term capital gains taxation applies. At the same time, the five-year capital gains share for the index may significantly proxy for the long-term tax burden, as our long-term tax rate may imperfectly capture the rate applicable to long-term shareholders. ${ }^{12}$

In regression 3, we only use the short-term, long-term tax difference to proxy for the cost of accelerating capital gains on the target firm, given the insignificance of the long-term tax burden variable in regression 2 . The cross-border tax difference is similarly estimated with a coefficient of -0.136 that is significant at the 5 percent level. The estimated coefficient on the short-long term tax difference is reduced slightly to 0.193 from 0.203 in regression 2, while it remains significant at 5 percent. This suggests that the positive estimated coefficient of the shortlong term tax difference in regression 2 is not solely driven by the negative correlation between this tax term and the long-term tax rate.

\footnotetext{
${ }^{12}$ As discussed in section 2, the long-term rate may depend on the investors' personal income tax bracket and on whether his holding is substantial or not.
} 
Next, we wish to control for corporate income taxation which may equally affect takeover outcomes. ${ }^{13}$ In regression 4 , we include the top corporate income tax rates of the acquirer and target countries. Both corporate tax rates are estimated to be insignificant. The coefficient on the cross-border tax difference becomes somewhat less negative at -0.129 , and it is significant at the $10 \%$ level. The estimated effect of the short-long term increases is slightly higher at 0.224 , and it is significant at the $1 \%$ level.

So far, we have assumed a holding period of 5 years as input into the calculation of all three capital gains tax variables. In regression 5, we alternatively assume an investment holding period of 3 years to compute our three tax variables in a regression analogous to regression 3 . The coefficient for the capitalization effect changes slightly to -0.142 , and is significant at 5 percent. The coefficient for the short-long tax term drops to 0.140 , and it is also significant at 5 percent.

Apart from taxation, the institutional environment in acquirer and target countries may affect merger outcomes, and in particular the takeover premium. Regression 6 includes proxies for acquirer and target country differences in indices of institutional quality in regression 3 . In particular, we consider an index for capital controls (with a higher value denoting less stringent capital controls), an index for the quality of the legal system (with a higher value denoting higher legal system quality), and an index of shareholder protection (with a higher value denoting better shareholder protection). All three institutional difference variables are estimated to be insignificant. This may reflect that there is little time variation in the included institutional indices in a regression that controls for target and acquirer country fixed effects. The two capital gains tax variables remain significant at the 5 percent level.

Regression 7 restricts the sample to domestic mergers. In this case, the cross-border tax difference variable is obviously zero, and no capitalization effect on takeover premiums for domestic mergers can be estimated. The influence of capital gains taxation is now limited to the short-long term tax difference, as our proxy for the cost of accelerating the realization of capital gains on target-firm shares. The estimated coefficient of the short-long tax difference is 0.197 , and it is significant at 5 percent. Thus, for domestic mergers we confirm a lock-in effect on takeover premiums.

\footnotetext{
${ }^{13}$ Huizinga, Voget and Wagner (2009) show that corporate income taxation that leads to international double taxation affects merger outcomes.
} 
While the previous regressions have been based on the sample of cash-transactions, regression 8 considers the sample of equity transactions. Capital gains taxation is expected to be immaterial in the equity-finance sample, confirming Hypothesis $4 .{ }^{14}$ The results indeed show that the tax variables lose their significance for equity swap transactions. Importantly, this finding suggests that the significant tax terms in the cash-finance regressions do not capture the effects of some omitted variable.

Regressions 1 to 8 are potentially subject to a sample selection problem, as capital gains taxation can affect the choice between cash and equity finance of a takeover as well as the takeover premium. Hypothesis 5 suggests that accrued and future capital gains tax burdens make cash financing more likely. This can bias the estimated coefficients in our premium regressions. ${ }^{15}$ To address this issue, we estimate a Heckman model, where in the first step the acquiring firm chooses between cash and equity finance, and in the second step it determines the premium for the cash transactions. In both steps, the included right-hand-side variables are as in regression 3. Regression 9 reports the results of the second-stage Heckman regression. The correlation between the error terms in the first and second stage, denoted rho, is shown to be negative and statistically significant. This is evidence of a sample selection problem.

The estimated coefficients for the capital gains tax variables in regression 9 are similar to those in regression 3 . The coefficient for the cross-border tax difference is slightly less negative at -0.110 , and significant at the 10 percent level. The coefficient on the short-term, long-term rate difference increases slightly to 0.225 , and is significant at the 1 percent level. These similar coefficients suggest that the sample selection bias has an only minor impact on the coefficients of interest.

Overall, our results suggest a significant capitalization effect of future capital gains taxes in takeover premiums, consistent with Hypothesis 1 . The estimated capitalization effect is economically significant. The coefficient for the cross-border tax term of -0.136 in regression 3 suggests that the average acquiring firm, subject to a long-term capital gains tax of 24.2 percent

\footnotetext{
${ }^{14}$ Capital gains tax effects should also be less important when institutional ownership is high. We attempted to collect institutional ownership for the firms in our sample, but found that using this information would reduce the sample size significantly.

${ }^{15}$ To see this, suppose that some aspect of capital gains taxation that potentially contributes to a lock-in effect is not fully accounted for by our capital gains tax variables. This aspect, when absent or immaterial, should make cash financing more likely, and at the same time reduce the takeover premium. The estimated coefficients for the included capital gains tax variables in the premium regression will be biased, if this left-out aspect of capital gains taxation is correlated with the included capital gains tax variables.
} 
from Table 5, pays a $3.29(=0.136 * 24.2)$ percent higher takeover price, if all acquiring countries abolish capital gains taxation. The impact of a relatively high short-term capital gains tax in the target country is also economically significant. The estimated coefficient on short-long difference of 0.193 in regression 3 suggests that the average target firm, with a mean short-term, long-term tax difference of 10.6 percent, obtains a takeover premium that is $2.05(=0.193 \times 10.6)$ percentage points higher than in the absence of capital gains taxation.

\subsection{The choice of payment}

The bidding firm faces the choice between payment in cash or in shares. Payment in cash may entail tax costs relative to equity finance, if the acquirer-country capital gains tax rate is high relative to the target-country tax rate. At the same time, cash finance implies the cost of realizing capital gains on the target-firm at the potentially higher short-term tax rate, and of accelerating the realization of gains that already quality for the lower long-term tax. Therefore, as stated in Hypothesis 5, we expect the propensity to use cash financing to decrease with i) the difference between the acquirer and the target country long-term rate, $t_{j}-t_{i}$, ii) the difference between the short and long term rate of the target country, $s_{i}-t_{i}$, and iii) the long term rate of the target country, $t_{i}$.

We start by looking at sample means, splitting our sample for each of the three tax terms into two parts according to the median of the respective tax term. As seen in column 4 of Table 4 , the proportion of cash transactions in the sample with a low cross-border tax differential $t_{j}-t_{i}$ is $85.0 \%$, while it is $61.8 \%$ in the high cross-border tax difference sample. The means for the two subsamples are significantly different from each other at 1 percent. This suggests that acquirers are more likely to offer cash if the acquirer-country tax rate is relatively high. In column 5, we see that the proportion of cash-transactions in the sample with a low difference between the target's short and long rates is $66.1 \%$, while it is $63.4 \%$ in the high tax difference sample. The two means are again significantly different at 1 percent. Thus, bidders tend to offer cash if the potential additional tax burden created by the application of short-term tax rates is low. In column 6 , we further see that the percentage of cash-transactions is $65.8 \%$ in the sample with the low long-term taxes, and it is $64.3 \%$ in the high long-term tax sample. The difference is significant at the $10 \%$ level. Thus, bidders tend to choose cash finance if target shareholders incur relatively low losses from not being able to defer long-term capital gains taxes any further. 
These results are all consistent with the hypothesis that cash finance is used if the capital tax costs of doing so are relatively modest.

Next, we examine the impact of our three capital gains tax terms on the choice of takeover financing by estimating a probit model. In this model, the dependent variable is a dummy variable that takes a value of one if the transaction has cash or hybrid cash-equity financing and a value of zero in case of equity financing. In addition to the tax variables, we consider a range of control variables at the level of the firms, the deal and the countries. The probit estimation includes target and bidder country fixed effects and year-fixed effects, and errors are clustered at the level of the target country.

Table 7 reports marginal effects, which are changes in the probability of a cash transaction induced by small changes in the independent variables on the assumption that all independent variables are at their means. Regression 1 also includes our three tax terms, analogously to regression 1 of Table 6 . The cross-border tax difference and the short-long term tax difference are estimated with marginal effects of -0.613 and -0.542 that are significant at the 1 and 5 percent levels, respectively. The target long rate enters with a negative coefficient that is statistically insignificant. This suggests that the cost of accelerating the realization of long-term capital gains has no significant impact on the means of payment for a takeover.

These estimated marginal effects are economically meaningful. To see this, consider that the average acquirer country with capital gains taxation, with a tax rate of 24.2 percent, would abolish its capital gains taxation. This would increase the probability of cash finance in crossborder takeovers by $14.8(=24.2 * 0.613)$ percentage points. Alternatively, we can consider that the average target country, with a short-long term tax difference of 10.6 percent, brings its shortterm rate down to the level of the long term rate. This would increase the probability of cash being offered by $5.7(=0.542 * 10.6)$ percentage points.

Several control variables included in regression 1 are estimated with significant coefficients. Among these, target size is estimated to have a negative and significant impact on the likelihood of cash financing, which may reflect that it is difficult to raise sufficient cash to purchase large targets. Liquid assets of the target are seen to make cash finance significant less likely. This could reflect that acquirer firms that wish to reduce their reliance on debt simultaneously purchase liquid targets and pay for them with equity. A high target-firm book-tomarket value appears to make cash finance more likely, perhaps because acquirer firms are 
prepared to make a risky cash offer if it concerns a target that looks relatively undervalued. Similarly, a high target-firm return on equity makes cash finance more likely, as high-return targets may be attractive enough to make a relatively risky cash offer. Furthermore, the intraindustry dummy is estimated to significantly decrease the probability of a cash transaction, possibly because target shareholders may be more ready to accept the shares of an acquirer firm in the same industry.

A potential explanation for the insignificance of the target long-rate in regression 1 is that it does not adequately capture the capital gains tax basis of long-term shareholders. The total capital gains tax burden taxed at the long rate is the product of the long rate itself and the appreciation of the marginal long-term target shareholder's investment. Analogously to regression 2 of Table 6 , we can construct a capital gains burden variable that is the product of the long term tax rate and the capital gains share of the target country's stock market index over the previous 5 years. In regression 2, we replace the long term tax rate by this capital gains tax burden variable and by the capital gains share for the index. Neither variable is estimated with significant coefficients. ${ }^{16}$ The estimated coefficients for the cross-border tax difference and the short-long term tax difference are almost unchanged.

Regression 3 includes the cross-border tax difference and short-long term tax difference variables, and it is similar to the first step of the Heckman two-step estimation of the takeover premium reported as regression 9 in Table 6. The estimated marginal effects for these two capital gains tax variables are very similar at -0.610 and -0.503 , and they are significant at 1 and 5 percent, respectively.

Regression 4 includes the acquirer and target country top corporate income tax rates in regression 1. Both tax rates are insignificant, while the cross-border tax difference and shortterm, long-term tax variables obtain essentially unchanged coefficients.

In regression 5, we compute all tax terms based on a holding period of 3 years rather than 5 years. The cross-border tax variable and the short-long term tax difference are estimated with very similar coefficients.

Regression 6 includes several proxies for the institutional environment in acquirer and target countries analogously to regression 6 of Table 6 . Of these, the difference in acquirer-

\footnotetext{
${ }^{16}$ We considered several variations of the capital gains basis for calculating the capital gains tax burden variable such as ones based on yearly average values of the index values and its lowest value during the preceding five years. None of these alternative tax burden variables was estimated to be significant.
} 
country legal quality relative to the target country is estimated with a negative coefficient that is significant at 5 percent. This means that acquirers located in countries with relatively highquality legal systems are more likely to offer equity. This makes sense as equity issued by firms located in countries with good legal systems may be more valuable.

Finally, in regression 7 we restrict the sample to domestic mergers. In this regression, the short-term, long-term tax difference is the only included capital gains tax variable. The estimated coefficient for this variable of -0.581 is very similar to previous regressions, and it is estimated to be significant at 10 percent.

Overall, our results indicate that capital gains tax considerations are an important determinant of the means of payment in M\&As. Specifically, an equity offer is more likely if the acquirer country has a relatively high capital gains tax rate (signaling a relatively high taxation of future capital gains) and if the target country has a relatively high short-term tax rate (signaling a high cost of accelerating the realization of short-term capital gains on target-firm shares). However, there is no evidence that the long-term tax rate in the target country affects the choice of payment for takeovers.

\section{Discussion of the results}

In this section, we first evaluate the implications of our results for the impact of capital gains taxation on asset pricing. Next, we consider how our results inform about the effective burden of capital gains taxation on shareholders and the cost of equity capital. Finally, we discuss some of the international repercussions of capital gains taxation.

\subsection{Capital gains taxation and asset pricing}

In section 5.1 we present evidence that firms located in countries with high capital gains taxation on shareholders pay less to acquire foreign targets. Specifically, the estimated coefficient for the cross-border tax difference variable of -0.136 in regression 3 of Table 6 suggests that the average acquiring firm pays $3.29\left(=0.136^{*} 24.2\right)$ percent less on account of capital gains taxation on shareholders, where 24.2 is the average long-term capital gains tax rate. This estimation essentially relates to the transferring of existing shares (of the target firm) to a new capital tax regime (of the acquiring country). A key question is to what extent our estimation informs about how capital gains taxation affects the pricing of new equity issues so as 
to finance real investment. There are several reasons to suspect that the capitalization effect of future capital gains taxation in the pricing of standard equity issues is somewhat larger than in cross-border takeover pricing.

To start, the takeover premium reflects the extent to which acquiring-firm shareholders can shift their capital gains taxation to target-firm shareholders by way of a lower premium. This pass-through is likely to be less than complete, which suggests that the full valuation of future capital gains taxation exceeds its discounting in the takeover premium. Research by Andrade, Mitchell and Stafford (2001) finds that most of the gains from M\&As tend to accrue to target shareholders. Interpreting gains as net-of-tax gains implies that acquirer-shareholders should be able to pass through their differential capital gains taxation almost fully to target-firm shareholders so that the discounting of acquiring-country capital gains taxation in takeover premiums underestimates the full incidence by only little.

Furthermore, our estimated discounts of capital gains taxation in equity prices are for the relatively large companies that undertake international takeovers. While such firms may represent a significant part of overall stock market capitalization, they differ importantly from smaller and younger firms that may issue shares to finance real investment. First, the returns that shareholders receive on the shares newer firms may be more heavily in the form of capital gains. Second, less mature firms may be owned more predominantly by domestic investors, which suggests that domestic capital gains taxation is relatively more important for the valuation of smaller firms. ${ }^{17}$ For both reasons, the impact of national capital gains taxation on firms in the start-up phase may be stronger than our estimated effect for firms that are active in the international takeover market.

Overall, we conclude that the discounting of future capital gains taxation in the pricing of new equity to finance real investment is likely to be stronger than the discounting of acquiringcountry capital gains taxation in takeover prices, especially for younger and smaller firms.

Our estimation shows that international takeover premiums are higher if the targetcountry short-term capital gains tax rate exceeds the long-term rate. This is evidence of a lock-in effect of capital gains taxation on takeover premiums. This lock-in effect on the takeover premium reflects the costs of accelerating the realization of capital gains at the time of the

\footnotetext{
${ }^{17}$ French and Poterba (1991) provide evidence of a considerable home bias in share portfolios so that it reasonable to assume that domestic firms are to a large extent owned by domestic shareholders.
} 
takeover, rather than any lock-in effect of capital gains taxation on share prices prior to the takeover. Our finding of a lock-in effect in the takeover premium suggests that there may be a lock-in effect on pre-takeover share prices as well, but our research does not directly address this issue. Thus, our research does not measure the full impact of capital gains taxation on firmvaluation in the secondary market.

\subsection{The effective burden of capital gains taxation and the cost of capital}

Our estimate of the impact of capital gains taxation on asset prices can be used to arrive at an estimate of the effective tax on capital gains. Protopapadakis (1983, p. 128) defines the effective capital gains tax as 'the tax rate on capital gains that, if levied continuously, would leave the investor with the identical wealth as a capital gains tax, $\tau$, levied when the capital gains tax are realized'. The effective rate of tax will be less than the statutory rate of tax, $\tau$, because of allowed deductions (of realized losses on other shares), exemptions, and the fact that investors only pay taxes when they realize their capital gains. Let $\rho$ be the effective tax on capital gains, and let $\sigma$ be the share of capital gains in total shareholders returns. We can then compute $\rho$ using the equation $\rho^{*} \sigma=0.136^{*} \tau$, which reflects that the effective capital gains tax only applies to the part of total shareholder returns represented by capital gains. ${ }^{18}$

To illustrate, we can compute $\sigma$ using historical returns on the MSCI World Index index over the 1970-2010 period. During this period, the average annual total shareholder return was 10.60 percent, which can be divided into an average capital gains return of 7.63 percent and an average dividend yield of 2.97 percent. The average capital gains share $\sigma$ in total returns can then be calculated as 0.720 . The effective capital gains tax rate - relative to the statutory tax rate- or $\rho / \tau$ then is $0.189(=0.136 / 0.720)$. Over the same $1970-2010$ period, the S\&P index had a very similar capital gains share of 0.723 , reflecting annual capital gains and dividend yields of 8.08 and 3.09 percent, so that the effective capital gains tax rate - relative to the statutory tax rate for the US can be computed as $0.188(=0.136 / 0.723)$.

This result can be compared to the estimate of effective capital gains taxation of Protopapadakis (129, Table 1) for the US in 1978, which is the final year in his study. In that year, the statutory capital gains tax rate in the US was 21.5 percent, while the effective tax rate is

\footnotetext{
${ }^{18}$ In this equation, we take the capital gains share in total shareholder returns to be constant. Chetty and Saez (2005), however, show that the US dividend tax cut from 35 percent to 15 percent enacted in 2003 caused many firms to initiate or increase dividend payments the following year.
} 
estimated to be in the 4.8-6.6 percent range, on the basis of individual investor data on asset holding periods and actual capital gains tax liabilities. This gives a range for the $\rho / \tau$ ratio of 0.223 - 0.307. Compared to Protopapadakis (1983), we thus find a somewhat lower estimate of the effective capital gains tax burden, which could reflect that stock trading strategies so as to lower the effective capital gains tax burden have become cheaper. ${ }^{19}$

Next, we consider the implications of the effective taxation of capital gains for the cost of capital using historical MSCI World Index data. ${ }^{20}$ The average effective tax rate $\rho$ can be calculated to be 4.57 percent, or 0.189 times the average capital gains tax rate $\tau$ of 24.2 percent. Thus the effective annual capital gains tax yield is seen to be 0.35 percent, or 4.57 percent times the annual capital gains tax yield of 7.63 on the MSCI World Index. This suggests that in the absence of capital gains, the total yield on the MSCI World Index 500 could have been 10.25 percent (the actual total pre-tax yield of 10.60 minus 0.35 ). Capital gains taxation then increases the cost of capital by 3.41 percent $(=100 * 0.35 / 10.25){ }^{21}$

\subsection{International repercussions of capital gains taxation}

National capital gains taxation affects takeover premiums in international M\&As. This implies that part of the economic incidence of capital gains taxation, as applied to cross-border M\&As, lies with foreign residents. A higher capital gains tax rate in the acquirer country, in particular, lowers the takeover premium paid by the acquiring firm. The acquiring country thus is able to export part of the incidence of its capital gains taxation to the target country.

In some instances, high capital gains taxation in a potential acquirer country may lower the acquiring-firm's reservation price by so much that an otherwise profitably international

\footnotetext{
${ }^{19}$ Our estimate of the effective burden of capital gains taxation as reflected in takeover prices, unlike the Protopapadakis (1983) figures, is inclusive of the excess burden created by capital gains taxation, which strengthens the conclusion that our study implies a lower effective taxation of capital gains taxation relative to statutory taxation. See Dammon, Spatt and Zhang (2001) for an analysis of how consumption and investment are distorted by capital gains taxation.

${ }^{20}$ Our estimation implies that capital gains taxation reduces a firm's average Tobin's q - defined as the market value of the firm divided by the replacement cost of the firm, which reduce the incentive for company creation and investment. We do not estimate the impact of capital gains taxation on a firm's marginal Tobin's q, defined as the market value of an extra unit of capital relative to cost. However, this should decline as well with capital gains taxation, reducing the incentive to invest at the margin.

${ }^{21}$ For the US the average long term capital gains tax rate over the 1985-2007 period was 22.74 percent. This implies an effective capital gains tax rate $\rho$ of $4.28(=0.188 * 22.74)$ percent using historical S\&P 500 data. The effective annual capital gains tax yield then is $0.35(=4.28 * 8.08 / 100)$. This suggests an increase in the cost of equity capital for firms of $3.23(=100 * 0.35 /(8.08+3.09-0.35)$ percent for US firms on account of capital gains taxation, very similar to the estimate of 3.41 percent for firms worldwide as based on MSCI World Index data and our sample average capital gains tax rate.
} 
takeover is prevented. At the same time, international differences in capital gains taxation may give rise to international clientele effects, increasing the likelihood that firms located in countries with low capital gains taxation acquire internationally.

We find that a higher short-term target tax rate increases the takeover premium. Thus, a relatively high short-term tax rate acts as a tax barrier to takeovers, and this tax is partly borne by foreigners in the case of cross-border takeovers.

These various international distortive and redistributive implications of capital gains taxation justify international coordination in the area of capital gains taxation. In the EU, this already exists in the form of the Mergers and Acquisitions Directive of 1990. However, the scope of this directive is limited to deals that have a cash-financing share of 10 percent or less, and thus leaves the implications of capital gains taxation of cash-financed deals, as studied in this paper, unchanged.

\section{Conclusion}

In a cross-border takeover, buyers and sellers are residents of different countries and hence subject to different regimes of capital gains taxation. This implies that international M\&As provide an ideal setting to study the impact of capital gains taxation on the two sides of transaction on merger outcomes. International takeovers provide a particularly interesting opportunity to estimate a capitalization effect associated with future capital gains taxation, as they induce an unanticipated transfer of the taxation of future capital gains from shareholders of the target country to shareholders of the acquirer country.

We find that a one percentage point increase in the acquirer-country capital gains tax rate reduces the takeover price by $0.136 \%$. The average country with capital gains taxation has a capital gains tax rate of $24.2 \%$. Capital gains taxes thus reduce the takeover price by an average $3.29(=0.136 * 24.2)$ percent, which is economically meaningful. Firms that issue new equity in the capital market can expect a similar discounting of shareholder capital gains. Our discount estimate implies that the effective capital gains tax, after taking account of deductions, exemptions, and deferral options, is about 19 percent of the statutory capital gains tax. For an average statutory capital gains tax rate of 24.6 percent, the average effective capital gains tax rate is thus calculated to be 4.57 percent. This implies that capital gains taxation significantly raises the cost of equity capital, potentially reducing investment in the economy. 
We also find that a relatively high target-country short-term capital gains rate creates a tax barrier to takeovers, as it leads target-firm shareholders to demand a higher takeover premium, to compensate for the realization of capital gains at the higher short-term rate. The higher takeover price is evidence of a lock-in effect of capital gains taxation on takeover prices. In the international economy, capital gains taxation can be distorting in the sense that it affects the international pattern of M\&As, and that it prevents some otherwise profitable M\&As from taking place at all. In particular, a firm in a country with relatively high capital gains taxation can offer only a relatively low takeover price on account of a significant capitalization effect. This potentially leads firms located in countries with high capital gains taxes to be less active as acquirers in the international takeover market. At the same time, a relatively high shortterm capital gains tax in a country may make takeovers of firms in that country, by both domestic and foreign firms, less likely. These distortions of the takeover market caused by capital gains taxation are undesirable. The introduction of a uniform capital gains tax rate for short-term and long-term capital gains in all countries would be a way to eliminate them. 


\section{References}

Andrade, Gregor, Mark Mitchell and Erik Stafford, 2001, New evidence and perspectives on mergers, Journal of Economic Perspectives 15, 103-120.

Auerbach, Alan J and Kevin A. Hassett, 2006, Dividend Taxes and Firm Valuation: New Evidence, American Economic Review, 96, 119-123.

Ayers, Benjamin C., Craig E. Lefanowicz and John R. Robinson, 2003, Shareholder taxes in acquisition premiums: the effects of the capital gains taxation, Journal of Finance 58, 2783-2801.

Brown, David T., and Michael D. Ryngaert, 1991, The model of acquisition in takeovers: taxes and asymmetric information, Journal of Finance 45, 653-669.

Chay, J.B., Dosung Choi, and Jeffrey Pontiff, 2006, Market valuation of tax-timing options: evidence from capital gains distributions, Journal of Finance 61, 837-865.

Comment Robert, and G. William Schwert, 1995, Poison or placebo? Evidence on the deterrence and wealth effects of modern takeover measures, Journal of Financial Economics 39, 3-43.

Chetty, Ray and Emmanuel Saez, 2005, Dividend Taxes and Corporate Behavior: Evidence from the 2003 Dividend Tax Cut, Quarterly Journal of Economics, 120, 791-833.

Dai, Zhonglan, Edward Maydew, Douglas A. Shackelford and Harald H. Zhang, 2008, Capital gains taxes and asset prices: capitalization or lock-in?, Journal of Finance.

Dammon, Robert M., Chester S. Spatt and Harold H. Zhang, 2001, Optimal consumption and investment with capital gains taxes, Review of Economic Studies 14, 583-616/

Faccio, Mara and Ronald W. Masulis, 2005, The choice of payment method in European mergers and acquisitions, Journal of Finance 60, 1345-1388.

French, Kenneth and James Poterba, 1991, Investor Diversification and International Equity Markets, American Economic Review 81, 222-26.

Guenther, David A. and Michael Willenborg, 1999, Capital gains tax rates and the cost of capital for small business: evidence from the IPO market, Journal of Public Economics 53, 385-408.

Gwartney, James and Robert Lawson with Herbert Grubel, Jakob de Haan, Jan-Egbert Sturm, and Eelco Zandberg (2009). Economic Freedom of the World: 2009 Annual Report. Vancouver, BC: The Fraser Institute.

Huizinga, Harry, Johannes Voget and Wolf Wagner, 2009. Who bears the burden of international taxation? Evidence from cross-border M\&As, mimeo, Tilburg University.

IBFD, 2008a. Global Tax Surveys. IBFD Publications, Amsterdam. 
IBFD, 2008b. Tax News Service. IBFD Publications, Amsterdam.

Ivković, Zoran, James Poterba and Scott Weisbenner, 2005. Tax-Motivated Trading by Individual Investors, American Economic Review, 95, 1605-1630.

Jin, Li, 2006, Capital gains tax overhang and price pressure, Journal of Finance 61, 1399-1431.

Lang, Mark H. and Douglas A. Shackelford, 2000, Capitalization of capital gains taxes: evidence from stock price reactions to the 1997 rate reduction, Journal of Public Economics, 76, 69-85.

Klein, Peter, 1999, The capital gain lock-in effect and equilibrium returns, Journal of Public Economics 71, 355-378.

Klein, Peter, 2001, The capital gain lock-in effect and long-horizon return reversal, Journal of Financial Economics 59, 33-62.

Klein, Peter, 2004, The capital gain lock-in effect and perfect substitutes, Journal of Public Economics 88, 2765-2783.

Lang, Mark H. and Douglas A. Shackelford, 2000, Journal of Public Economics 76, 69-85.

McGrattan, Ellen R. and Edward C. Prescott, 2005, Taxes, regulations, and the value of U.S. and U.K. corporations, Review of Economic Studies 72, 767-796

Officer, Micah S., 2003, Termination fees in mergers and acquisitions, Journal of Financial Economics 69, 431-467.

Protopapadakis, Aris, 1983, Some indirect evidence on effective capital gains tax rates, Journal of Business 56, 127-138.

Reese, William A. Jr., 1998, Capital gains taxation and stock market activity: evidence from IPOs, Journal of Finance 53, 1799-1819.

Schwert, G. William, 1996, Markup pricing in mergers and acquisitions, Journal of Financial Economics 41, 153-192.

Sialm, Clemens, 2009, Tax Changes and Asset Pricing, American Economic Review, 99, 135683.

Spamann, Holger, 2010, The "Antidirector Rights Index" Revisited, The Review of Financial Studies, 23, 467-86. 
Appendix A. Variable definitions and data sources

\begin{tabular}{lll}
\hline Variable & Description & Sources \\
\hline Cash & $\begin{array}{l}\text { Dummy signaling that acquisition is financed by cash of by cash and } \\
\text { equity }\end{array}$ & Thomson SDC
\end{tabular}

Premium

Cross-border difference

Target short-long difference

Target long rate

Target burden based on index

Capital gains based on index

Corp. income tax rate acquirer

Corp. income tax rate target

Difference capital controls

acquirer target

Difference legal systems

acquirer target

Difference shareholder

protection acquirer target

Market value

\section{Leverage}

Liquidity ratio

Book-to-market

ROE
Bid premium computed as ratio of bid price and the share price four weeks before announcement minus the ratio of the target country stock market index and the target country stock market index four weeks before the announcement

Difference in forward-looking capital gains tax rates between acquirer and target for holding period of 5 year.

Difference between capital gains tax rate of target for holding periods of 1 day and 5 years in target country

Capital gains tax rate of the target for holding period of 5 years

Capital gains tax rate in target country for holding period of 5 years multiplied by the ratio of appreciation on the stock market index of target country during previous 5 years and contemporaneous level of stock market index

Ratio of appreciation on the stock market index of target country during previous 5 years and contemporaneous level of stock market index

Top corporate income tax rate of the acquirer country

Top corporate income tax rate of the target country

Difference between acquirer and target percentage of capital controls

not levied as a share of the total number of considered capital controls

Difference between acquirer and target index of the quality of the legal structure and the security of property rights

Difference between acquirer and target index of the quality of the legal structure and the security of property rights.

Log of market value of target four weak prior to announcement in millions of U.S. dollars

Ratio of liabilities and assets of the target

Ratio of liquid assets to total assets in target

Book value of target divided by its market value 4 weeks prior to announcement

Return on equity
Thomson SDC

IBFD (2008a, 2008b)

IBFD (2008a, 2008b)

IBFD (2008a, 2008b)

Datastream, IBFD (2008a, 2008b)

Datastream

IBFD (2008a, 2008b)

Gwartney et al. (2009)

Gwartney et al. (2009)

Spamann (2010)

Datastream, Thomson SDC

Thomson SDC

Compustat NA, Compustat Global, and Thomson SDC

Compustat NA, Compustat Global, and Thomson SDC

Compustat NA, Compustat Global, and Thomson SDC

Compustat NA, Compustat Global, and Thomson 
Competing bid

Hostile

Tender Toehold
Dummy variable signaling that there is a competing bid

Dummy variable signaling an offer that is not supported by target

board

Dummy variable signaling there is a tender offer for all stocks

Percentage acquirer ownership in target prior to merger
SDC

Thomson SDC

As above

As above As above 
Table 1: Capital gains taxation of individuals in 2007

\begin{tabular}{|c|c|c|c|}
\hline & $\begin{array}{l}\text { Long run } \\
\text { cash } \\
\text { nonsubst. }\end{array}$ & $\begin{array}{l}\text { Short run } \\
\text { cash } \\
\text { nonsubst. }\end{array}$ & $\begin{array}{l}\text { Long-run } \\
\text { threshold } \\
\text { in years }\end{array}$ \\
\hline & 1 & 2 & 3 \\
\hline Australia & 22.5 & 45 & 1 \\
\hline Austria & 0 & 50 & 1 \\
\hline Belgium & 0 & 0 & \\
\hline Canada & 23.1 & 23.1 & \\
\hline Croatia & 0 & 0 & \\
\hline Czech Republic & 0 & 32 & 0.5 \\
\hline Denmark & 43 & 43 & 3 \\
\hline Estonia & 22 & 22 & \\
\hline Finland & 28 & 28 & \\
\hline France & 0 & 27 & 8 \\
\hline Germany & 0 & 23.7 & 1 \\
\hline Greece & 0 & 0 & \\
\hline Hungary & 20 & 20 & \\
\hline Ireland & 20 & 20 & \\
\hline Italy & 12.5 & 12.5 & 1 \\
\hline Japan & 20 & 10 & $2 \mathrm{a}$ \\
\hline Latvia & 0 & 0 & \\
\hline Lithuania & 0 & 15 & 1 \\
\hline Luxembourg & 0 & 39 & 0.5 \\
\hline Mexico & 0 & 0 & \\
\hline Netherlands & 0 & 0 & \\
\hline New Zealand & 0 & 0 & \\
\hline Norway & $28 \mathrm{~b}$ & $28 \mathrm{~b}$ & \\
\hline Poland & 19 & 19 & \\
\hline Portugal & 0 & 10 & 1 \\
\hline Slovak Rep & 19 & 19 & \\
\hline South Korea & 0 & 0 & \\
\hline Spain & 18 & 18 & 1 \\
\hline Sweden & 30 & 30 & \\
\hline Switzerland & 0 & 0 & \\
\hline Turkey & 0 & 10 & 1 \\
\hline United Kingdom & 32 & 40 & $6 \mathrm{c}$ \\
\hline United States & $20 \mathrm{~d}$ & 35 & 1 \\
\hline
\end{tabular}

The top rate is assumed to apply in case of several tax brackets. The share of stocks is assumed to be less than one percent of outstanding stocks. (Different tax codes may apply to substantial shareholders in some countries.) The reported rates apply to capital gains in listed firms.

Footnotes:

a The lower rate of $10 \%$ applied only from 2003 to 2008. In 2009, the capital gains tax rate increased back to $20 \%$ as scheduled. $\mathrm{b}$ Dividends and capital gains are exempt up to the respective risk free return on capital during the holding period according $\mathrm{t}$ the shielding method.

c The capital gains tax base is gradually reduced by 5 percentage points for the third, fourth, fifth and sixth year of holding an asset. $\mathrm{d}$ The maximum tax rate on capital gains is $15 \%$ for capital assets disposed of after 6 May 2003 and before 1 January 2009. The reduced $15 \%$ tax rate on qualified dividends and long term capital gains, introduced 6 May 2003 and previously scheduled to expire in 2008, was extended through 2010 as a result of the Tax Reconciliation Act signed into law by President George W. Bush on May 17, 2006. This was extended through 2012 by President Barack Obama on Dec 17, 2010. 
Table 2. Summary information on capital tax rates by holding period in 2007

\begin{tabular}{lllll}
\hline Holding period & Mean & Std. dev. & Min & Max \\
\hline 1 day & 18.77 & 0.152 & 0.00 & 50.00 \\
1 year & 12.03 & 0.134 & 0.00 & 43.00 \\
2 years & 12.34 & 0.134 & 0.00 & 43.00 \\
3 years & 12.28 & 0.133 & 0.00 & 43.00 \\
4 years & 12.37 & 0.133 & 0.00 & 43.00 \\
5 years & 12.31 & 0.131 & 0.00 & 43.00 \\
6 years & 11.98 & 0.128 & 0.00 & 43.00 \\
7 years & 11.70 & 0.128 & 0.00 & 43.00 \\
8 years & 11.43 & 0.129 & 0.00 & 43.00 \\
\hline
\end{tabular}

The table presents the cross-country average capital gains tax rates for individuals. Rates apply to assets acquired in 2007 and to be exchanged for cash and are in percent. The average rates differ by the length of the period during which the asset was held. For holding periods longer than 8 years, the average tax rate remains invariant. For individual countries, the rate is the top rate in case there is a schedule, and rates apply to non-substantial holdings of less than one percent of outstanding stocks. 
Table 3. Summary information for takeovers

\begin{tabular}{|c|c|c|c|c|c|c|c|c|c|c|c|c|}
\hline & \multicolumn{4}{|c|}{ International takevoers by target nation } & \multicolumn{4}{|c|}{ International takeovers by acquirer nation } & \multicolumn{4}{|c|}{ Domestic takeovers } \\
\hline & Number & $\begin{array}{l}\text { Total value } \\
\text { of } \\
\text { transactions }\end{array}$ & $\begin{array}{c}\text { Mean } \\
\text { premium }\end{array}$ & $\%$ Cash & Number & $\begin{array}{c}\text { Total value } \\
\text { of } \\
\text { transactions }\end{array}$ & $\begin{array}{c}\text { Mean } \\
\text { premium }\end{array}$ & $\%$ Cash & Number & $\begin{array}{c}\text { Total value } \\
\text { of } \\
\text { transactions }\end{array}$ & $\begin{array}{c}\text { Mean } \\
\text { premium }\end{array}$ & $\%$ Cash \\
\hline Australia & 111 & 49,892 & 0,45 & 77,48 & 69 & 60,012 & 0,38 & 76,81 & 304 & 111,531 & 0,32 & 52,63 \\
\hline Austria & 6 & 2,450 & 0,52 & 100,00 & 8 & 1,145 & 0,28 & 100,00 & 5 & 4,326 & 0,33 & 100,00 \\
\hline Belgium & 15 & 15,600 & 0,31 & 86,67 & 32 & 22,481 & 0,45 & 81,25 & 15 & 43,983 & 0,36 & 73,33 \\
\hline Canada & 167 & 128,281 & 0,45 & 73,05 & 181 & 154,142 & 0,44 & 70,17 & 341 & 137,126 & 0,36 & 41,06 \\
\hline Croatia & 2 & 2,818 & 0,36 & 100,00 & & & & & & & & \\
\hline Cz. Republic & 4 & 1,225 & 0,35 & 100,00 & & & & & 1 & 0,006 & 0,15 & 100,00 \\
\hline Denmark & 20 & 27,330 & 0,40 & 85,00 & 30 & 22,590 & 0,55 & 96,67 & 15 & 16,656 & 0,36 & 66,67 \\
\hline Estonia & & & & & 1 & 0,180 & 0,13 & 100,00 & & & & \\
\hline Finland & 16 & 12,521 & 0,37 & 75,00 & 18 & 20,119 & 0,53 & 77,78 & 9 & 2,395 & 0,51 & 55,56 \\
\hline France & 90 & 60,617 & 0,31 & 90,00 & 168 & 214,519 & 0,50 & 86,90 & 154 & 256,205 & 0,29 & 79,87 \\
\hline Germany & 47 & 52,567 & 0,26 & 93,62 & 137 & 258,370 & 0,43 & 89,05 & 32 & 55,582 & 0,34 & 68,75 \\
\hline Greece & 5 & 3,988 & 0,24 & 100,00 & 7 & 5,999 & 0,36 & 85,71 & 12 & 4,215 & 0,15 & 33,33 \\
\hline Hungary & 6 & 0,537 & 0,17 & 100,00 & & & & & 4 & 0,315 & 0,36 & 100,00 \\
\hline Ireland & 19 & 19,085 & 0,41 & 84,21 & 30 & 11,111 & 0,46 & 76,67 & 15 & 9,051 & 0,34 & 66,67 \\
\hline Italy & 17 & 18,625 & 0,29 & 82,35 & 61 & 94,997 & 0,45 & 91,80 & 46 & 91,397 & 0,34 & 78,26 \\
\hline Japan & 16 & 13,736 & 0,34 & 100,00 & 69 & 61,151 & 0,50 & 97,10 & 357 & 335,656 & 0,28 & 51,82 \\
\hline Latvia & 1 & 0,025 & 0,14 & 100,00 & & & & & & & & \\
\hline Lithuania & 3 & 1,620 & 0,38 & 100,00 & & & & & & & & \\
\hline Luxembourg & 2 & 3,927 & 0,49 & 0,00 & 12 & 19,234 & 0,30 & 83,33 & 2 & 36,008 & 0,72 & 0,00 \\
\hline Mexico & 4 & 1,587 & 1,07 & 100,00 & 5 & 21,649 & 0,76 & 100,00 & 4 & 32,511 & 0,41 & 50,00 \\
\hline Netherlands & 50 & 191,116 & 0,45 & 68,00 & 114 & 307,773 & 0,43 & 87,72 & 37 & 29,531 & 0,33 & 81,08 \\
\hline New Zealand & 23 & 8,984 & 0,34 & 91,30 & 12 & 5,063 & 0,35 & 100,00 & 32 & 3,805 & 0,30 & 84,38 \\
\hline Norway & 37 & 15,358 & 0,45 & 81,08 & 16 & 8,243 & 0,41 & 93,75 & 44 & 18,486 & 0,35 & 75,00 \\
\hline Poland & 16 & 1,389 & 0,18 & 100,00 & 2 & 1,502 & 0,19 & 100,00 & 3 & 0,827 & 0,10 & 66,67 \\
\hline Portugal & 2 & 0,052 & 0,48 & 100,00 & 2 & 0,156 & 0,39 & 100,00 & 2 & 2,069 & 0,67 & 100,00 \\
\hline Slovakia & & & & & 1 & 0,024 & 0,38 & 100,00 & 1 & 0,000 & 0,31 & 100,00 \\
\hline
\end{tabular}




\begin{tabular}{|c|c|c|c|c|c|c|c|c|c|c|c|c|}
\hline South Korea & 3 & 0,530 & 0,45 & 100,00 & 4 & 0,981 & 0,26 & 100,00 & 9 & 11,915 & 0,44 & 33,33 \\
\hline Spain & 16 & 61,934 & 0,29 & 87,50 & 34 & 150,449 & 0,34 & 73,53 & 26 & 40,005 & 0,24 & 69,23 \\
\hline Sweden & 57 & 73,936 & 0,44 & 77,19 & 74 & 49,339 & 0,44 & 89,19 & 70 & 29,088 & 0,31 & 64,29 \\
\hline Switzerland & 19 & 23,973 & 0,32 & 68,42 & 93 & 141,710 & 0,47 & 92,47 & 14 & 68,434 & 0,22 & 64,29 \\
\hline Turkey & 1 & 2,258 & 0,07 & 100,00 & & & & & 2 & 0,196 & 0,18 & 100,00 \\
\hline UK & 435 & 688,312 & 0,48 & 88,74 & 356 & 547,073 & 0,45 & 85,11 & 828 & 505,112 & 0,43 & 62,92 \\
\hline USA & 802 & 1036,145 & 0,49 & 85,79 & 476 & 340,405 & 0,46 & 82,98 & 4.944 & 5499,888 & 0,45 & 52,71 \\
\hline Total & 2.012 & 2520,416 & 0,45 & 84,69 & 2.012 & 2520,416 & 0,45 & 84,69 & 7.328 & 7346,317 & 0,42 & 54,82 \\
\hline
\end{tabular}

Value of transactions is in billions of U.S. dollars. The premium is the net premium and it is computed as a share. \% cash is the percentage of cash transactions. 
Table 4. Summary statistics of premium, cash, tax and control variables.

\begin{tabular}{lccccc}
\hline & $\begin{array}{c}\text { Number of } \\
\text { observations }\end{array}$ & Average & $\begin{array}{c}\text { Standard } \\
\text { deviation }\end{array}$ & Minimum & Maximum \\
\hline Premium & 9,394 & 0,422 & 0,329 & 0 & 1,979 \\
\% Cash & 9,394 & 0,616 & 0,486 & 0 & 1 \\
Cross-border difference & 9,152 & $-0,008$ & 0,077 & $-0,470$ & 0,430 \\
Target short-long difference & 9,394 & 0,106 & 0,098 & 0 & 0,570 \\
Target long rate & 9,394 & 0,242 & 0,097 & 0 & 0,560 \\
Market value & 9,364 & 4793283 & 1765989 & 0,956 & 8751411 \\
Leverage & 8,778 & 0,554 & 0,256 & 0 & 1 \\
Liquidity ratio & 7,983 & 0,292 & 0,549 & 0,001 & 0,740 \\
Book-to-market ratio & 8,971 & 0,771 & 0,598 & 0 & 3,191 \\
ROE & 8,897 & $-0,001$ & 0,188 & $-0,888$ & 0,167 \\
Same industry & 9,394 & 0,300 & 0,458 & 0 & 1 \\
Subsidiary & 9,394 & 0,008 & 0,088 & 0 & 1 \\
Competed & 9,394 & 0,075 & 0,264 & 0 & 1 \\
Hostile & 9,394 & 0,035 & 0,184 & 0 & 1 \\
Tender & 9,394 & 0,415 & 0,493 & 0 & 1 \\
Toehold & 9,394 & 3,944 & 10,940 & 0 & 96,3 \\
\hline
\end{tabular}

Notes. The premium is the net premium and it is computed as a share. \% cash is the percentage of cash transactions. For other variable definitions, see Appendix A. 
Table 5. The premium and cash transactions in low and high tax variable samples

\begin{tabular}{l|c|c|c|lccc}
\hline & \multicolumn{3}{|c|}{ Premium } & \multicolumn{3}{c}{$\%$ Cash } \\
\hline & $\begin{array}{c}\text { Cross- } \\
\text { border tax } \\
\text { difference }\end{array}$ & $\begin{array}{c}\text { Target } \\
\text { short- } \\
\text { long } \\
\text { difference }\end{array}$ & $\begin{array}{c}\text { Target } \\
\text { long rate }\end{array}$ & $\begin{array}{l}\text { Cross- } \\
\text { border } \\
\text { tax } \\
\text { difference }\end{array}$ & $\begin{array}{c}\text { Target } \\
\text { short- } \\
\text { long } \\
\text { difference }\end{array}$ & $\begin{array}{c}\text { Target } \\
\text { long } \\
\text { rate }\end{array}$ \\
\hline Low tax variable sample & 46.95 & 41.78 & 41.55 & 85.00 & 66.14 & 65.76 \\
High tax variable sample & 41.82 & 43.33 & 43.24 & 61.83 & 63.43 & 64.35 \\
T-test of equal means & $4.85^{* * *}$ & $-2.24^{* *}$ & $-2.50^{* *}$ & $18.27^{* * *}$ & $3.45^{* * *}$ & $1.85^{*}$ \\
Signs as predicted? & Yes & Yes & Yes & Yes & Yes & Yes \\
\hline
\end{tabular}

The premium is the net premium and it is computed as a share. \% cash is the percentage of cash transactions. 
Table 6. Capital gains taxes and the takover premium

\begin{tabular}{|c|c|c|c|c|c|c|c|c|c|}
\hline VARIABLES & $\begin{array}{c}(1) \\
\text { All tax terms }\end{array}$ & $\begin{array}{c}(2) \\
\text { Tax basis of } \\
\text { index }\end{array}$ & $\begin{array}{c}\text { (3) } \\
\text { Two tax terms }\end{array}$ & $\begin{array}{c}(4) \\
\text { Corp. income } \\
\operatorname{tax} \\
\end{array}$ & $\begin{array}{c}\text { (5) } \\
\text { Holding period } \\
\text { of } 3 \text { years }\end{array}$ & $\begin{array}{c}\text { (6) } \\
\text { Institutional } \\
\text { quality }\end{array}$ & $\begin{array}{c}(7) \\
\text { Domestic } \\
\text { mergers }\end{array}$ & $\begin{array}{c}(8) \\
\text { Equity } \\
\text { transactions } \\
\end{array}$ & $\begin{array}{c}(9) \\
\text { Heckman }\end{array}$ \\
\hline Cross-border difference & $\begin{array}{l}-0.151 * * \\
(0.0681)\end{array}$ & $\begin{array}{l}-0.135 * * \\
(0.0631)\end{array}$ & $\begin{array}{l}-0.136 * * \\
(0.0634)\end{array}$ & $\begin{array}{l}-0.129 * \\
(0.0658)\end{array}$ & & $\begin{array}{l}-0.145^{* *} \\
(0.0554)\end{array}$ & & $\begin{array}{l}-0.0141 \\
(0.243)\end{array}$ & $\begin{array}{l}-0.110^{*} \\
(0.0608)\end{array}$ \\
\hline $\begin{array}{l}\text { Target short-long } \\
\text { difference }\end{array}$ & $\begin{array}{l}-0.0595 \\
(0.0913)\end{array}$ & $\begin{array}{l}0.203 * * \\
(0.0775)\end{array}$ & $\begin{array}{l}0.193 * * \\
(0.0808)\end{array}$ & $\begin{array}{l}0.224 * * * \\
(0.0560)\end{array}$ & & $\begin{array}{l}0.188^{* *} \\
(0.0832)\end{array}$ & $\begin{array}{l}0.197 * * \\
(0.0906)\end{array}$ & $\begin{array}{c}0.0417 \\
(0.0893)\end{array}$ & $\begin{array}{l}0.225 * * * \\
(0.0836)\end{array}$ \\
\hline Target long rate & $\begin{array}{c}-0.450 * * \\
(0.171)\end{array}$ & & & & & & & & \\
\hline $\begin{array}{l}\text { Target burden based on } \\
\text { index }\end{array}$ & & 0.253 & & & & & & & \\
\hline $\begin{array}{l}\text { Capital gains based on } \\
\text { index }\end{array}$ & & $\begin{array}{l}0.0562 * \\
(0.0297)\end{array}$ & & & & & & & \\
\hline $\begin{array}{l}\text { Corporate income tax rate } \\
\text { target } \\
\text { Corporate income tax rate } \\
\text { acquirer }\end{array}$ & & & & $\begin{array}{l}0.0820 \\
(0.180) \\
-0.313 \\
(0.397)\end{array}$ & & & & & \\
\hline $\begin{array}{l}\text { Cross-border difference, } 3 \text { - } \\
\text { years }\end{array}$ & & & & & $\begin{array}{l}-0.142 * * \\
(0.0682)\end{array}$ & & & & \\
\hline $\begin{array}{l}\text { Target short-long } \\
\text { difference, } 3 \text { years }\end{array}$ & & & & & $\begin{array}{l}0.140^{*} \\
(0.0827)\end{array}$ & & & & \\
\hline $\begin{array}{l}\text { Difference capital controls } \\
\text { acquirer-target }\end{array}$ & & & & & & $\begin{array}{r}-0.000927 \\
(0.00337)\end{array}$ & & & \\
\hline $\begin{array}{l}\text { Difference legal systems } \\
\text { acquirer-target }\end{array}$ & & & & & & $\begin{array}{l}-0.00928 \\
(0.0101)\end{array}$ & & & \\
\hline $\begin{array}{l}\text { Difference shareholder. } \\
\text { protection acquirer-target }\end{array}$ & & & & & & $\begin{array}{l}0.00897 \\
(0.0125)\end{array}$ & & & \\
\hline Market value & $\begin{array}{l}-0.0269 * * * \\
(0.00267)\end{array}$ & $\begin{array}{c}-0.0267 * * * \\
(0.00272)\end{array}$ & $\begin{array}{l}-0.0269 * * * \\
(0.00273)\end{array}$ & $\begin{array}{l}-0.0268 * * * \\
(0.00273)\end{array}$ & $\begin{array}{c}-0.0269 * * * \\
(0.00271)\end{array}$ & $\begin{array}{c}-0.0268 * * * \\
(0.00273)\end{array}$ & $\begin{array}{c}-0.0288 * * * \\
(0.00195)\end{array}$ & $\begin{array}{c}-0.0375 * * * \\
(0.00418)\end{array}$ & $\begin{array}{c}-0.0239 * * * \\
(0.00268)\end{array}$ \\
\hline Leverage & $\begin{array}{c}0.00546 * * * \\
(0.00185)\end{array}$ & $\begin{array}{l}0.00524 * * * \\
(0.00190)\end{array}$ & $\begin{array}{l}0.00542 * * * \\
(0.00186)\end{array}$ & $\begin{array}{l}0.00542 * * * \\
(0.00186)\end{array}$ & $\begin{array}{c}0.00543 * * * \\
(0.00186)\end{array}$ & $\begin{array}{c}0.00544 * * * \\
(0.00180)\end{array}$ & $\begin{array}{c}0.00621 * * * \\
(0.00194)\end{array}$ & $\begin{array}{c}0.00728 * * * \\
(0.00196)\end{array}$ & $\begin{array}{c}0.00533 * * * \\
(0.00200)\end{array}$ \\
\hline Liquidity ratio & $0.0204 * * *$ & $0.0210 * * *$ & $0.0202 * * *$ & $0.0203 * * *$ & $0.0201 * * *$ & $0.0201 * * *$ & 0.00574 & $0.0246 * *$ & $0.0247 * * *$ \\
\hline
\end{tabular}




\begin{tabular}{|c|c|c|c|c|c|c|c|c|c|}
\hline & $(0.00612)$ & $(0.00614)$ & $(0.00594)$ & $(0.00599)$ & $(0.00579)$ & $(0.00568)$ & $(0.00817)$ & $(0.0114)$ & $(0.00477)$ \\
\hline \multirow[t]{2}{*}{ Book-to-market ratio } & $0.0812 * * *$ & $0.0826 * * *$ & $0.0817 * * *$ & $0.0817 * * *$ & $0.0816^{* * *}$ & $0.0815 * * *$ & $0.0903 * * *$ & $0.0499 * * *$ & $0.0766^{* * *}$ \\
\hline & $(0.00919)$ & $(0.00865)$ & $(0.00904)$ & $(0.00898)$ & $(0.00911)$ & $(0.00939)$ & $(0.00945)$ & $(0.0126)$ & $(0.00716)$ \\
\hline \multirow[t]{2}{*}{ ROE } & $-0.0224 * *$ & $-0.0243 * * *$ & $-0.0225 * * *$ & $-0.0226 * *$ & $-0.0228 * * *$ & $-0.0231 * * *$ & -0.0160 & -0.0197 & $-0.0314 * * *$ \\
\hline & $(0.00827)$ & $(0.00748)$ & $(0.00819)$ & $(0.00837)$ & $(0.00816)$ & $(0.00789)$ & $(0.0144)$ & $(0.0208)$ & $(0.00989)$ \\
\hline \multirow[t]{2}{*}{ Same industry } & $0.0287 * * *$ & $0.0288 * * *$ & $0.0291 * * *$ & $0.0293 * * *$ & $0.0290 * * *$ & $0.0294 * * *$ & $0.0359 * * *$ & $-0.0219 * *$ & $0.0291 * * *$ \\
\hline & $(0.00743)$ & $(0.00733)$ & $(0.00723)$ & $(0.00731)$ & $(0.00727)$ & $(0.00736)$ & $(0.00844)$ & $(0.00817)$ & $(0.00714)$ \\
\hline \multirow[t]{2}{*}{ Subsidiary } & -0.00784 & -0.00145 & -0.00705 & -0.00638 & -0.00695 & -0.00862 & 0.00122 & -0.0626 & 0.00145 \\
\hline & $(0.0337)$ & $(0.0339)$ & $(0.0333)$ & $(0.0330)$ & $(0.0332)$ & $(0.0333)$ & $(0.0259)$ & $(0.0678)$ & $(0.0319)$ \\
\hline \multirow[t]{2}{*}{ Competed } & $0.117 * * *$ & $0.118 * * *$ & $0.117 * * *$ & $0.116 * * *$ & $0.117 * * *$ & $0.117 * * *$ & $0.117 * * *$ & $0.106 * * *$ & $0.113 * * *$ \\
\hline & $(0.0269)$ & $(0.0271)$ & $(0.0267)$ & $(0.0263)$ & $(0.0267)$ & $(0.0256)$ & $(0.0209)$ & $(0.0352)$ & $(0.0279)$ \\
\hline \multirow[t]{2}{*}{ Hostile } & $0.0915 * * *$ & $0.0888 * *$ & $0.0888 * *$ & $0.0904 * *$ & $0.0886^{* *}$ & $0.0885 * *$ & $0.0953^{*}$ & 0.0489 & $0.0843 * *$ \\
\hline & $(0.0326)$ & $(0.0350)$ & $(0.0336)$ & $(0.0333)$ & $(0.0334)$ & $(0.0341)$ & $(0.0489)$ & $(0.0446)$ & $(0.0349)$ \\
\hline \multirow[t]{2}{*}{ Tender } & $0.0834 * * *$ & $0.0821 * * *$ & $0.0838 * * *$ & $0.0834 * * *$ & $0.0837 * * *$ & $0.0835 * * *$ & $0.0860 * * *$ & $0.0496 * * *$ & $0.0545 * * *$ \\
\hline & $(0.0121)$ & $(0.0124)$ & $(0.0124)$ & $(0.0126)$ & $(0.0125)$ & $(0.0117)$ & $(0.0130)$ & $(0.0158)$ & $(0.00822)$ \\
\hline \multirow[t]{2}{*}{ Toehold } & $-0.00173 * * *$ & $-0.00169 * * *$ & $-0.00171 * * *$ & $-0.00171 * * *$ & $-0.00172 * * *$ & $-0.00175 * * *$ & $-0.00163 * * *$ & $-0.00173 * * *$ & $-0.00171 * * *$ \\
\hline & $(0.000230)$ & $(0.000226)$ & $(0.000228)$ & $(0.000222)$ & $(0.000229)$ & $(0.000222)$ & $(0.000368)$ & $(0.000518)$ & $(0.000226)$ \\
\hline \multirow[t]{2}{*}{ Rho } & & & & & & & & & $-0.1873 * * *$ \\
\hline & & & & & & & & & $(0.07240)$ \\
\hline Observations & 4,780 & 4,778 & 4,780 & 4,780 & 4,780 & 4,754 & 3,385 & 2,715 & 7,495 \\
\hline R-squared & 0.207 & 0.207 & 0.206 & 0.206 & 0.205 & 0.204 & 0.209 & 0.187 & \\
\hline
\end{tabular}

The dependent variable is the takeover premium. See the Appendix for variable definitions and data sources. All regressions include year, industry and acquirer and target country fixed effects. The sample consists of cash transactions only in columns 1-7 and 9, and of equity transactions only in column 9. Standard errors are clustered at the level of the target country. $\left({ }^{* * *} \mathrm{p}<0.01,{ }^{* *} \mathrm{p}<0.05,{ }^{*} \mathrm{p}<0.1\right)$ 
Table 7. Capital gains taxes and the choice of payment for the takeover

\begin{tabular}{|c|c|c|c|c|c|c|c|}
\hline VARIABLES & $\begin{array}{c}(1) \\
\text { All tax terms }\end{array}$ & $\begin{array}{c}\text { (2) } \\
\text { Tax basis of } \\
\text { index }\end{array}$ & $\begin{array}{c}(3) \\
\text { Two tax terms }\end{array}$ & $\begin{array}{l}\text { (4) } \\
\text { Corp. income } \\
\text { tax }\end{array}$ & $\begin{array}{c}\text { (5) } \\
\text { Holding period } \\
\text { of } 3 \text { years }\end{array}$ & $\begin{array}{c}\text { (6) } \\
\text { Institutional } \\
\text { quality }\end{array}$ & $\begin{array}{c}(7) \\
\text { Domestic } \\
\text { mergers }\end{array}$ \\
\hline Cross-border difference & $\begin{array}{c}-0.613 * * * \\
(0.201)\end{array}$ & $\begin{array}{c}-0.604 * * * \\
(0.204)\end{array}$ & $\begin{array}{c}-0.610 * * * \\
(0.202)\end{array}$ & $\begin{array}{c}-0.541 * * * \\
(0.183)\end{array}$ & & $\begin{array}{c}-0.693 * * * \\
(0.187)\end{array}$ & \\
\hline Target short-long difference & $\begin{array}{c}-0.542 * * \\
(0.271)\end{array}$ & $\begin{array}{c}-0.473 * * \\
(0.232)\end{array}$ & $\begin{array}{c}-0.503 * * \\
(0.221)\end{array}$ & $\begin{array}{c}-0.530 * * \\
(0.209)\end{array}$ & & $\begin{array}{c}-0.524 * * * \\
(0.197)\end{array}$ & $\begin{array}{c}-0.581 * \\
(0.312)\end{array}$ \\
\hline Target long rate & $\begin{array}{l}-0.0707 \\
(0.302)\end{array}$ & & & & & & \\
\hline Target burden based on index & & $\begin{array}{l}-0.0738 \\
(0.380)\end{array}$ & & & & & \\
\hline Capital gains based on index & & $\begin{array}{r}-0.0922 \\
(0.108)\end{array}$ & & & & & \\
\hline Corporate income tax rate target & & & & $\begin{array}{c}0.460 \\
(0.369)\end{array}$ & & & \\
\hline Corporate income tax rate acquirer & & & & $\begin{array}{l}-0.0996 \\
(1.149)\end{array}$ & & & \\
\hline Cross-border difference, 3 years & & & & & $\begin{array}{c}-0.601 * * * \\
(0.198)\end{array}$ & & \\
\hline Target short-long difference 3 years & & & & & $\begin{array}{l}-0.514 * * \\
(0.222)\end{array}$ & & \\
\hline $\begin{array}{l}\text { Difference capital controls acquirer- } \\
\text { target }\end{array}$ & & & & & & $\begin{array}{c}-0.000412 \\
(0.0238)\end{array}$ & \\
\hline Difference legal systems acquirer-target & & & & & & $\begin{array}{c}-0.0930^{* *} \\
(0.0373)\end{array}$ & \\
\hline $\begin{array}{l}\text { Difference shareholder protection } \\
\text { acquirer-target }\end{array}$ & & & & & & $\begin{array}{c}0.0567 \\
(0.0519)\end{array}$ & \\
\hline Market value & $\begin{array}{c}-0.0365 * * * \\
(0.00739)\end{array}$ & $\begin{array}{c}-0.0371 * * * \\
(0.00764)\end{array}$ & $\begin{array}{c}-0.0365 * * * \\
(0.00739)\end{array}$ & $\begin{array}{c}-0.0368 * * * \\
(0.00772)\end{array}$ & $\begin{array}{r}-0.0364 * * * \\
(0.00741)\end{array}$ & $\begin{array}{c}-0.0363 * * * \\
(0.00739)\end{array}$ & $\begin{array}{c}-0.0445 * * * \\
(0.00733)\end{array}$ \\
\hline Leverage & $\begin{array}{c}0.00265 \\
(0.00197)\end{array}$ & $\begin{array}{c}0.00262 \\
(0.00189)\end{array}$ & $\begin{array}{c}0.00264 \\
(0.00195)\end{array}$ & $\begin{array}{c}0.00268 \\
(0.00194)\end{array}$ & $\begin{array}{c}0.00260 \\
(0.00196)\end{array}$ & $\begin{array}{c}0.00254 \\
(0.00196)\end{array}$ & $\begin{array}{c}0.00212 \\
(0.00258)\end{array}$ \\
\hline Liquidity ratio & $\begin{array}{c}-0.0770 * * * \\
(0.0185)\end{array}$ & $\begin{array}{c}-0.0781 * * * \\
(0.0186)\end{array}$ & $\begin{array}{c}-0.0771 * * * \\
(0.0184)\end{array}$ & $\begin{array}{c}-0.0774 * * * \\
(0.0184)\end{array}$ & $\begin{array}{c}-0.0768 * * * \\
(0.0183)\end{array}$ & $\begin{array}{c}-0.0760 * * * \\
(0.0174)\end{array}$ & $\begin{array}{c}-0.0822 * * * \\
(0.00999)\end{array}$ \\
\hline Book-to-market ratio & $\begin{array}{l}0.0738^{*} \\
(0.0388)\end{array}$ & $\begin{array}{l}0.0723^{*} \\
(0.0376)\end{array}$ & $\begin{array}{l}0.0738^{*} \\
(0.0388)\end{array}$ & $\begin{array}{l}0.0739 * \\
(0.0385)\end{array}$ & $\begin{array}{l}0.0741^{*} \\
(0.0387)\end{array}$ & $\begin{array}{l}0.0749^{*} \\
(0.0385)\end{array}$ & $\begin{array}{l}0.0834 * \\
(0.0447)\end{array}$ \\
\hline
\end{tabular}




$\begin{array}{ccccccc}0.0635^{* * *} & 0.0645^{* *} & 0.0635^{* * *} & 0.0638^{* * *} & 0.0636^{* * *} & 0.0653 * * * & 0.0623 * * \\ (0.0241) & (0.0254) & (0.0242) & (0.0246) & (0.0242) & (0.0243) & (0.0284) \\ -0.163 * * * & -0.163 * * * & -0.163 * * * & -0.163 * * * & -0.162 * * * & -0.164 * * * & -0.175^{* * *} \\ (0.0180) & (0.0182) & (0.0181) & (0.0184) & (0.0183) & (0.0184) & (0.0197) \\ 0.103 & 0.103 & 0.103 & 0.100 & 0.104 & 0.107 & 0.144 \\ (0.118) & (0.117) & (0.117) & (0.119) & (0.116) & (0.119) & (0.133) \\ -0.136 & -0.140^{*} & -0.136 & -0.135 & -0.134 & -0.131 & -0.162 \\ (0.0851) & (0.0832) & (0.0849) & (0.0836) & (0.0835) & (0.0858) & (0.105) \\ 9,286 & & & & & 9,245 & 7,365 \\ 0.13 & 9,282 & 9,286 & 9,286 & 9,286 & 0.14 & 0.12\end{array}$

Pseudo R-square

The dependent variable is a dummy variable is equals 1 for a cash or hybrid offer and 0 for an equity offer. See the Appendix for variable definitions and data sources. Coefficients are marginal effects from probit regressions. All regressions include year, industry and acquirer and target fixed effects. Standard errors are clustered at the level of the target country. $(* * \mathrm{p}<0.01, * * \mathrm{p}<0.05, * \mathrm{p}<0.1)$ 
Figure 1. Capital gains tax rates for long holding period during 1985-2007

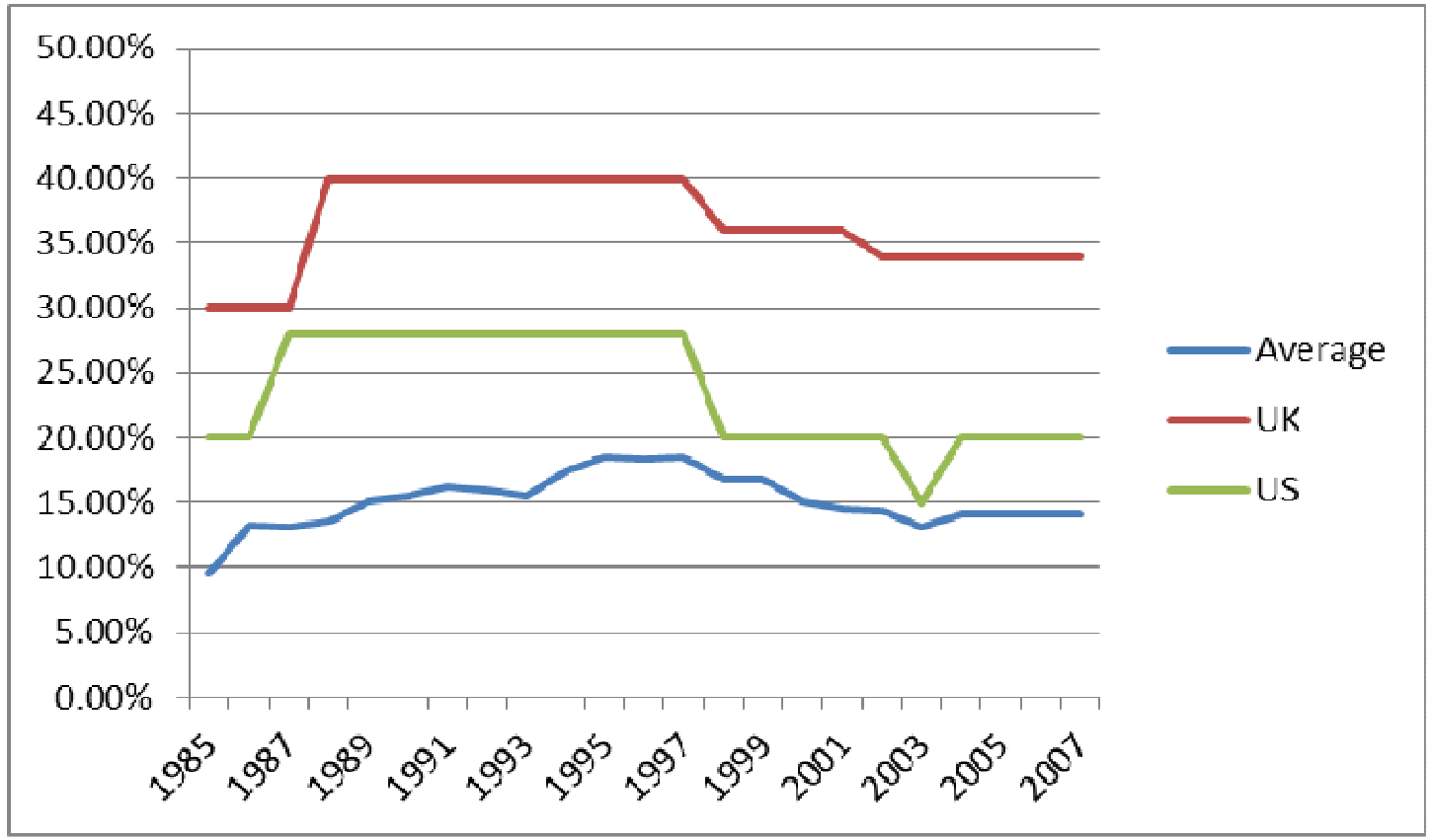

Rates apply to assets acquired in a given year and to be exchanged for cash by individuals. For individual countries, the rate is the top rate in case there is a schedule, and rates apply to non-substantial holdings of less than one percent of outstanding stocks.

Figure 2. Capital gains tax rates for short holdings periods during 1985-2007

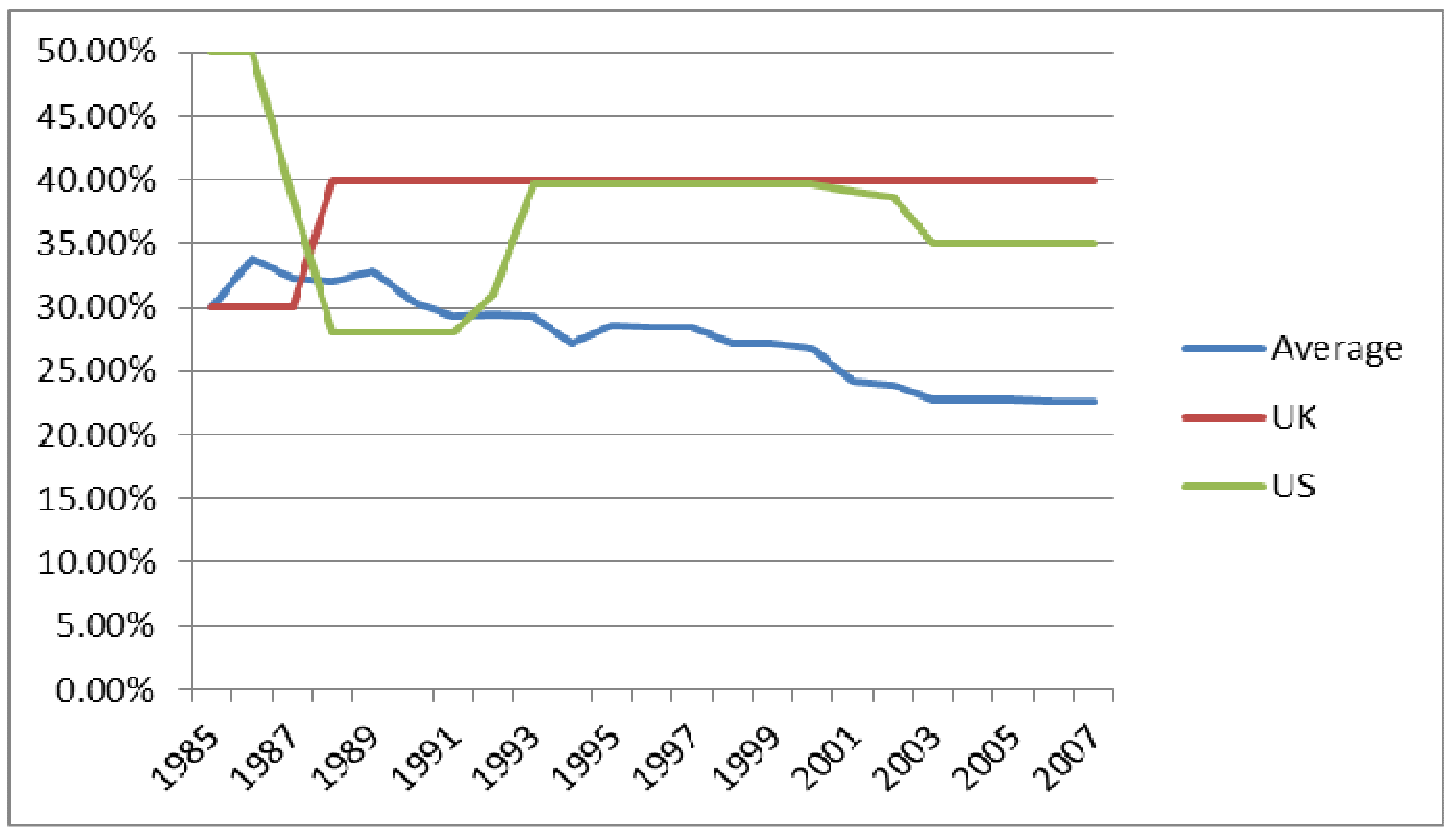

Rates apply to assets acquired in a given year and to be exchanged for cash by individuals. For individual countries, the rate is the top rate in case there is a schedule, and rates apply to non-substantial holdings of less than one percent of outstanding stocks. 